\title{
The Challenges and Enhancing Opportunities of Global Project Management: Evidence from Chinese and Dutch Cross-Cultural Project Management
}

\section{Citation}

Zhang, Ying, Christopher Marquis, Sergey Filippov, Henk-Jan Haasnoot, and Martijn van der Steen. "The Challenges and Enhancing Opportunities of Global Project Management: Evidence from Chinese and Dutch Cross-Cultural Project Management." Harvard Business School Working Paper, No. 15-063, February 2015.

\section{Permanent link}

http://nrs.harvard.edu/urn-3:HUL.InstRepos:13993638

\section{Terms of Use}

This article was downloaded from Harvard University's DASH repository, and is made available under the terms and conditions applicable to Open Access Policy Articles, as set forth at http:// nrs.harvard.edu/urn-3:HUL.InstRepos:dash.current.terms-of-use\#OAP

\section{Share Your Story}

The Harvard community has made this article openly available.

Please share how this access benefits you. Submit a story.

\section{Accessibility}


H A R VAR D

The Challenges and Enhancing Opportunities of Global Project Management: Evidence from Chinese and Dutch CrossCultural Project Management

Ying Zhang Christopher Marquis Sergey Filippov Henk-Jan Haasnoot Martijn van der Steen

\section{Working Paper}

15-063

February 11, 2015 
The Challenges and Enhancing Opportunities of Global Project Management: Evidence from Chinese and Dutch Cross-Cultural Project Management

\author{
Ying Zhang \\ Rotterdam School of Management \\ Erasmus University Rotterdam \\ y.zhang@,rsm.nl
}

\title{
Christopher Marquis
}

Harvard Business School

Harvard University

cmarquis@hbs.edu

\section{Sergey Filippov}

The Lisbon Council Economic Competitiveness and Social Renewal, Brussels sergey.filippov@lisboncouncil.net

Henk-Jan Haasnoot

KPMG the Netherlands

Haasnoot.Henk-Jan@kpmg.nl

\section{Martijn van der Steen}

KPMG the Netherlands

vanderSteen.Martijn@,kpmg.nl 


\title{
The Challenges and Enhancing Opportunities of Global Project Management:
}

Evidence from Chinese and Dutch Cross-Cultural Project Management

\begin{abstract}
:
This study investigates the role of national and organisational culture in day-to-day activities of multinational project teams, specifically focusing on differences between Chinese and Dutch project managers. We rely on fieldwork observation and interviews with representatives from a diverse set of organizations in China and the Netherlands. Analyses focus on the impact of cultural differences on five project management processes - (1) project planning, (2) cost and quality management, (3) risk management, (4) scope management and project promises, and (5) communication. Although there are many differences observed in these five processes, research subjects report no significant impact of crosscultural collaboration on project performance. We conclude that cross-cultural project teams can provide critical elements for an effective combination of different project management practices: people from various national and organisational cultures, enriched by different experiences and management theories, with a mix of skills. This study provides insights for those who work cross culturally (especially between western and eastern contexts) and is also a contribution to both the project management and crosscultural management literatures.
\end{abstract}

Key words: project management, culture, project performance, innovation, China

JEL: M10, M14, O31

Disclaimer: Sergey Filippov, Martijn van der Steen and Henk-Jan Haasnoot write here in a personal capacity. The views and opinions expressed in this publication are solely those of the authors and do not necessarily state or reflect those of the organisations they are affiliated with. 


\section{Executive Summary}

The aim of this study is to investigate the role of national and organisational culture in day-to-day activities of multinational project teams. We specifically focus on differences between the diverse cultural contexts of Chinese and Dutch project managers.

As for a research methodology we rely on field work observations and interviews with a number of representatives from organisations belonging to various industries, such as oil, food, commodity trading, product design and engineering, accountancy, both in China and the Netherlands. Additionally, we have interviewed scholars at Chinese and Dutch universities and diplomats from both sides. We have recognised a number of practical problems and thought-provoking work patterns based on four different scenarios embracing locations (either China or the Netherlands) and employees' cultural orientation (either Chinese or Dutch employees). We have focused on three elements central in project management - process, people and technology. As a result of this study, we have formulated a number of conclusions.

First, when Dutch and Chinese managers work on the same project, the key factors for project management are people and process, based on the assumption that technology is identical to all participants in the globalisation process. People's cognition and approach to conduct project management is largely determined by their perception and reflective perceived behaviour. The behaviour is determined by the cognition that people embrace, mainly shaped by the external environment of national culture, organisational culture, and/or individual "culture" deriving from aforementioned two cultures as well as personal traits. In such a way, process, as one of the key elements of project management, moderated by culture and mainly determined by people, will lead to variations in project performance.

Second, the role of organisational culture is larger than the role of national culture in shaping people's attitude and mind-set in the process of project management, maybe because organisational culture has to be easily adapted to the different host countries such that its symptoms of symbols and rituals can be sustainably serving the organisations for being consistent to the core of the national culture - the value.

From our observation, there are a few differences between the Chinese and Dutch in the project process:

(1) The Dutch are more formalised in the project planning process and stick more to the preagreed planning, while the Chinese pay less attention to planning. They execute projects with a very high pace, learning by doing, in a trial-and-error approach. Therefore, the Chinese act more dynamically and efficiently in the execution stage. The Dutch spend a large part of project time in the planning stage, with the purpose of foreseeing and trying to prevent as many errors and unnecessary mistakes that might be happening later on when the project is in execution.

(2) In terms of cost and quality management, Chinese are more focused on cost tracking in order to be competitive, and hence potentially sacrificing quality. As for scheduling and speed, the Chinese have 
a hierarchical governance structure but fast decision-making process. As for the Dutch, they pay attention to cost and benefits management and stick to quality control. The Dutch share a more cooperative structure so the decision-making process can be longer.

(3) In terms of risk management, the Chinese have a higher risk appetite due to their entrepreneurial spirit, but risk management is not formalised. The Dutch are more risk-averse; they spend more time on identifying risk beforehand with a more formalised risk management system in place.

(4) In terms of scope management and project promises, the Chinese seem to be rather flexible with project goals, which are subject to changes while project is in execution. The Dutch stick to the project goals formulated at project initiation and follow a more formalised scope management process.

(5) In terms of communication, a larger power distance in China implies that open communication in the hierarchical structure is not usual. In contrast, the Dutch hold a different approach with a transparent communication system, open to all project team members.

With all these points, there is a gap in rate of progress between the Chinese and Dutch. The Dutch progress slower, with highly formalised and recurring processes (e.g. regular status reports). The Chinese care more about speed of delivery with less formalised progress management.

Third, we have not identified any significant cross-cultural gap in project performance between the Chinese and Dutch, although there have been many differences in the process as aforementioned. Working approaches of the Chinese and Dutch have their own pros and cons. A combination of both approaches may lead to a win-win situation and be beneficial for project performance. For instance, the Chinese are strong in incremental innovative projects and a trial-and-error approach, while the Dutch feel comfortable in disruptive innovation projects, and are far more advanced in planning. Interestingly, satisfaction and project performance are rated quite high when people of both cultures work jointly on the same project. This satisfaction is even higher for Dutch managers with working experience in China partnering with Chinese managers who have a prior experience of working with Dutch colleagues.

This study is of critical significance for those individuals who work on cross-cultural projects in a global economy. An active and open tendency to working cross-culturally will be beneficial to organisations. However it will only happen when organisations are aware of fundamental cultural differences and have a dynamic project management system in place. Our study shows that people of two opposite cultures (the Chinese and Dutch) are able to work together in a project-based environment, to complement each other and reap mutual benefits for a win-win result. 


\section{Introduction}

Project management is of great importance in today's world as it is relevant to almost every industry sector. The literature on project management has evolved considerably over the recent years, with a largeamount of research carried out in various aspects of project management (Kwak and Anbari, 2009; Söderlund, 2004; Turner, 2010; Wintera et al, 2006). As the field of project management is maturing in theory and practically globalisation calls for an increased interaction between people of different countries and cultures, it has witnessed a "projectification" of the world led by a growing number of specialists organising their work in projects rather than on on-going functional basis.

In this big trend, it has been recognised that the most remarkable development in the global economy is the rise of Asian economies, and specifically China. The country has become a global economic powerhouse and has become more likely to act as an important "coordinative position" in global supply chains. One of the direct results is the wide presence of virtually all top western multinational companies in China, which operate in a large range of sectors - from construction to advanced engineering and R\&D. Working with Chinese has become a "must" job in internationalisation and globalisation process. But same time it is also a challenging job for many people and organisations from western countries, as cultural aspects have occupied a prominent place in the project management discipline, ranging from the analysis of cross-national cultural differences (Pheng and Leong, 2000; De Bony, 2010; Rees-Caldwell and Pinnington, 2013) to the impact of organisational culture on project performance (Gajendran et al, 2012; Wiewiora et al, 2013; Ching Gu et al, 2014). All of these have granted the study of project management and project management tools and approaches a critical role in crossculture project management (if admitting the globalisation).

Therefore, in this study, we depart from the previous studies that remain pertinent and represent a fertile field of research. We aim to contribute to the literature on cross-culture project management and explicitly seek to derive practical managerial implications for people who work in cross-cultural project environments consisting of Asian (Chinese) and European (Dutch) colleagues.

The paper is structured as follows. Section 2 sets the context and provides a brief introduction of the current stage of the evolution of project management field with a special focus on cultures. Section 3 outlines the methodology and explains the data collection process. Section 4 presents empirical results; and Section 5 concludes.

\section{Culture in Project Management}

Project management as a human activity has a centuries-long history, starting from the building of the Egyptian pyramids. However, as a formalised discipline, project management is rather young. Maylor (2005) determines three major stages of the PM historical development. Before the 1950s, project management as such was not recognised. In the 1950s, the dominant thinking of project management was based on "one best way" approach, based on numerical methods, tools and techniques. From the 1990s 
onwards, project management is more and more contingent upon its context, from sole project management to the broader management of projects and strategic project management (Fangel, 1993; Morris, 1994; Bryde, 2003). To a large extent, project management is much more than a set of tools, graphs and charts. It is essentially a set of people management skills and techniques. A perfect project plan will never be realised if an unprofessional project team with poor leadership is executing the project; however a strong project team may compensate deficiencies in a project plan. Hence, organisational behaviour, as a field of study, has direct relation to project management.

\subsection{Culture and Organisations}

Such broader understanding of project management, and specifically a prominent role of the human component therein, has naturally called for the examination of the project management - culture nexus. Culture can be studied in two dimensions - National Culture and Organisational Culture, i.e. culture specific to people united in a particular professional group (Denison and Mishra, 1995; Schneider, 1990).

According to Hofstede (1997), one of the most renowned authors in cross-cultural management, the author of "Cultures and Organisations: Software of the Mind", "Culture is the collective programming of the mind distinguishing the members of one group or category of people from others". His recent publication ${ }^{1}$ presents that culture, derived from anthropology, is the collective ways of acting, thinking, and feeling. As such, national culture locates in the category of nation, and organisational culture roots in the category of organisation. The reason of importance of the role of culture in everything (including in this case of project management) is that "the culture is a construct that is not directly accessible to observation but inferably from verbal statements and other behaviours and useful in predicting other observable and measureable verbal and nonverbal behaviours" (Levitin, 1973).

In the category of national culture, Hofstede identified four dimensions to measure (quantify) national cultures, and later a fifth one was added: (1) Power distance index (PDI): "Power distance is the extent to which the less powerful members of organisations and institutions (like the family) accept and expect that power is distributed unequally". (2) Individualism (IDV) vs. collectivism: “The degree to which individuals are integrated into groups". In individualistic societies, the stress is put on personal achievements and individual rights. In contrast, individuals in collectivist societies act predominantly as members of a lifelong and cohesive group or organisation. (3) Uncertainty avoidance index (UAI): "a society's tolerance for uncertainty and ambiguity". It reflects the extent to which members of a society attempt to cope with anxiety by minimising uncertainty. (4) Masculinity (MAS) vs. femininity: “The distribution of emotional roles between the genders". Masculine cultures' values are competitiveness, assertiveness, materialism, ambition and power, whereas feminine cultures place more value on relationships and quality of life. (5) Long-term orientation (LTO) vs. short-term orientation describes

\footnotetext{
${ }^{1}$ https://www.bbvaopenmind.com/en/article/national-cultures-organizational-cultures-and-the-role-ofmanagement/
} 
societies' time horizons. Long-term oriented societies attach more importance to the future; whereas in short term oriented societies, values promoted are related to the past and the present.

Whereas all national cultures are distinctively different, a stream of literature has sought to group national cultures for analytical purposes. A recent study by Ronen and Shenkar (2013) extends and builds on Ronen and Shenkar's synthesised cultural clustering of countries based on similarity and dissimilarity in work-related attitudes, therefore, eleven global clusters are identified, varying from the highly cohesive Arab and Anglo clusters to the least cohesive Confucian and Far Eastern clusters - Arab, Near East, Latin America, East Europe, Latin Europe, Nordic, Germanic, African, Anglo, Confucian, Far East.

\subsection{Culture and Project Management}

Following the seminal works of Hofstede and Trompenaars, and further studies, it is widely acknowledged that national culture exerts its influence on the way individuals act and work. Project-based environment differs from on-going, operation-type of work. By their definition, projects are transient (with clearly defined beginning and end), specific phases and milestones and expected deliverables. Considering such specifics of project based environments, as well as the importance of "people management" in projects, cultural differences may manifest themselves in projects quite vigorously. In his analysis of the impact of national culture on project performance, Turner (2009) explicitly relates the Hofstede dimensions to stages of the project life cycle. Typically, this life cycle includes: (1) feasibility exploration whether a project is reasonable venture worth doing at all, (2) design - preparing a specific plan of actions, including budgeting, risk register, quality plan, etc, (3) execution - actual execution of this plan, (4) close-out - finalisation of the project. Seemingly, each of these stages requires different sets of personal skills and capabilities. For example, while creativity is highly valued at the design stages, it is less relevant at the execution stage, when one needs to follow a strictly defined plan.

Table 1 Preferred Cultural Approach at Each Stage of the Life Cycle

\begin{tabular}{lllll}
\hline \hline Trait & Feasibility & Design & Execution & Close-out \\
\hline Power distance PDI & High & Low & Low & High \\
Individualism IDV & High & Medium & Medium & Low \\
Masculinity MAS & Medium & Medium & Medium & Medium \\
Uncertainty avoidance UAI & Low & Medium & Medium & High \\
\hline \hline
\end{tabular}

Source: Turner (2009), p. 401 
As presented in Table 1, in terms of power distance PDI, strong leadership is necessary to get the project started and going, and hence such leader should be recognised and accepted by all project team members. Lower power distance is required in the project design and execution stages when the project team acts in a more egalitarian manner. At the project close-out phase, once again, strong leadership is essential to finalise the project.

In terms of the dimension of individualism (IDV): People start working in a project team as individuals. In the feasibility phase, everyone is welcome to express his/her view directly and openly, e.g. in brainstorming sessions, for the sake of creativity. In the later stages, individualism slowly gives way to collectivism as project members engage in project work, as common goal (project objective) unites individuals and forms a collective identity.

Masculinity (MAS) remains medium throughout the whole project life cycle - neither strongly masculine nor feminine. Essentially, it means there is a need for constant balance between compromises and harmony (feminine) and drive forward to success (masculine).

By definition, every project is unique, thus by definition there is uncertainty upfront. Regarding uncertainty avoidance $(\mathrm{UAI})$, it is medium throughout the project.

According to such categorisation, national cultures can be ranked according to their fitness for project management. For instance, the French national culture, with its high individualism and large power distance would perfectly fit the feasibility stage; the German nationals, with lower power distance and medium individualism, would fit in the design and execution stages.

The second dimension of culture that we treat in the context of project management is Organisational Culture: the behaviour of humans who are part of an organisation and the meanings that these individuals attach to their actions. This culture includes the organisation values, visions, norms, working language, systems, symbols, beliefs and habits. Ravasi and Schultz (2006) define organisational culture as a set of shared mental assumptions that guide interpretation and action in organisations by defining appropriate behaviour for various situations. Likewise, according to Needle (2004), organisational culture represents the collective values, beliefs and principles of organisational members and is a product of such factors as history, product, market, technology, and strategy, type of employees, management style, and national cultures and so on. While a company may have one shared organisational culture, larger firms witness diverse and even conflicting co-existing cultures and sub-cultures (Deal and Kennedy, 2000; Schein, 2009).

In the studies of integrating national culture and organisational culture, Hofstede stressed that organisational culture cannot trump national culture (ITAP International, 20142) through his few qualitative and quantitative studies. He elaborated that evidence particularly in the global movements of merger and acquisitions shows that national culture values are learned much earlier, held deeply, and

2 http://www.itapintl.com/index.php/about-us/latest-news/57-organizational-culture-and-national-culture-what-sthe-difference-and-why-does-it-matter 
change slowly over the course of generations, while organisational culture is comprised of broad guidelines and rooted in organisational practices learned on the job (ITAP International, 2014). Although national cultures differ mostly at the level of values, while organisational cultures differ mostly at the level of the more superficial practice such as symbols, heroes and rituals (Hofstede, 1980; Hofstede et al., 1990), the impact of the culture on the cross-border project management keeps us being curious to investigate in this study.

\section{Data and Methodology}

We collected the data from various (senior) professionals with experience in project management in both European and Chinese contexts. With regard to culture, we observed and generated the constructs by observing and listening to the concepts of the culture and interviewees' indicated perception on the cross-culture project management. The interviewees came from a large variety of industries both in China and the Netherlands, such as sectors of oil and gas, commodity trading, food processing, product design and engineering, and accountancy. They all embraced cross culture project management experience in China and the Netherlands. Some of them had already lived in the other country for a while.

The conversation was not only about their experience in working in a cross-culture project team, but also the experience working (if they had) in a non-cross-culture project team. The respondents were given full freedom to reflect for instance on the nature of cultural differences in a project based environment, and the impact of such differences on the project success. In addition, we paid attention to respondents' tones, attitude in the responding, etc. All respondents were given a brief description of Hofstede's cultural dimensions; they were asked to characterise their opposing culture (either Chinese or Dutch) along each of these dimensions. Next, all respondents were asked to provide their opinion on how this national culture influences project management in each of the following aspects - such as cost and benefit management, governance and decision-making, quality management, planning, risk and issue management, scope management, progress management and communication. The brief question was also asked to express the weight between organisational and national culture.

To generate the patterns from our observation, we conducted several rounds of analysis, crossing different tiers of data aggregation. The interviews were semi-structured in an informal setting that allowed respondents to reflect and provide their thoughts in full.

In principle, we analysed our observations in four conceptual scenarios (Table 2). Two scenarios present the situation when an individual works on a project in his/her home country (either a Dutch person in the Netherlands, or a Chinese in China). The other two scenarios represent typical situations of cross-cultural project management (either a Dutch person on a project in China, or a Chinese person on a project in the Netherlands). 
Table 2 Four scenarios of cross-cultural management

\begin{tabular}{|c|c|c|}
\hline \multirow{2}{*}{ Individual } & \multicolumn{2}{|c|}{ Country / National Culture } \\
\cline { 2 - 3 } & China & The Netherlands \\
\hline Chinese & $\begin{array}{c}\text { Chinese person working on a project in } \\
\text { China (home) }\end{array}$ & $\begin{array}{c}\text { Chinese person working on a project } \\
\text { in The Netherlands }\end{array}$ \\
\hline Dutch & Dutch person working on a project in \\
& China & $\begin{array}{c}\text { Dutch person working on a project in } \\
\text { The Netherlands (home) }\end{array}$ \\
\hline
\end{tabular}

We extracted key information from the interviews focusing on two main variables - the role of national and organisational culture and the performance of project management. In our analysis, inductive reasoning was used. This means that whereas we used the extant body of literature on cross-cultural management as a background of our study, we did not derive and put forward a set of testable hypotheses. Inductive reason leads to a conclusion that is reached by generalising or extrapolating from initial information in an open domain, with epistemic uncertainty, such as in cultural studies.

To have robust findings, we also collected data from the representatives of public organisations, such as the Chinese Embassy in the Netherlands, International Chamber of Commerce and universities both in China and the Netherlands. Such a representative sample gives us confidence in the robustness and representativeness of obtained results.

The abstract data can be found in the appendix (Appendix A and Appendix B)

\section{Results}

\subsection{Explaining Cultural Differences between the Chinese and Dutch}

We firstly consulted The Hofstede Centre (www.geert-hofstede.com) that provides up-to-date scores for most national cultures derived from World Values Survey data. We retrieved the data for the Chinese and Dutch national cultures. Figure 1 presents scores along five dimensions. Accordingly, if we follow the study of Turner (2009), Chinese should be fit more in the feasibility stage in the project life cycle due to Chinese higher level of PDI and lower UAI and Dutch should be fit more in the stage of design due to their lower PDI and medium UAI. 


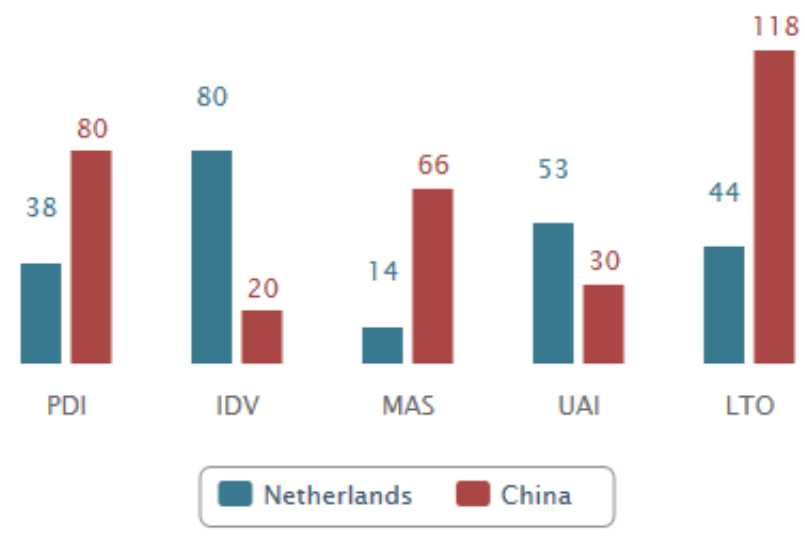

Figure 1 Scores along Hofstede's Dimensions for China and the Netherlands

Source: Compiled by authors at http://geert-hofstede.com/national-culture.html

Secondly, we patterned our observations and identify the national culture difference between Dutch and Chinese over five dimensions, presented in Table 3. The Chinese exhibit a very high power distance and low individualism. It means that they attach more importance of being a part of a group, in which there is a clear hierarchy. The boss makes all decisions and the involvement in this process of subordinates is minimal. For instance, a typical Chinese project team member will wait until the decision has been made by the project leader, and this decision will be unquestioningly executed. In contrast, the Dutch have the minimal distance, and at the same time high individualism. It entails that the society is egalitarian and decision-making process is inclusive. Therefore, for Dutch, while decisions can be taken collectively, every project team member preserves his/her individual mindset and does not necessarily attach that much value to being a part of the project team.

Table 3 Comparative Analysis of the Chinese and Dutch Cultures along Hofstede's Dimensions

\begin{tabular}{|c|c|c|}
\hline \multirow[t]{2}{*}{ Dimension } & \multicolumn{2}{|c|}{ Country / National Culture } \\
\hline & China & The Netherlands \\
\hline Power Distance & $\begin{array}{ll}- & \text { Boss decides, team members } \\
\text { execute } \\
\text { - } & \text { Less \& indirect feedback } \\
\text { - } & \text { Knowing decision makers } \\
\text { important, but hard }\end{array}$ & $\begin{array}{ll}\text { - } & \text { Team decides } \\
\text { - } & \text { Delegate duties \& responsibilities }\end{array}$ \\
\hline Individualism & $\begin{array}{ll}\text { - } & \text { Importance of trust \& building } \\
\text { relations } \\
\text { - } & \text { Social control }\end{array}$ & $\begin{array}{l}\text { - } \text { Group decision making } \\
\text { - } \quad \text { Comfortable with rapid team } \\
\text { changes }\end{array}$ \\
\hline Masculinity & $\begin{array}{l}\text { - Rapid achievement \& success } \\
\text { - Long working hours }\end{array}$ & $\begin{array}{ll}\text { - } & \text { Work/life balance } \\
\text { - } & \text { Job satisfaction }\end{array}$ \\
\hline Uncertainty & - Try-and-error approach & - $\quad$ Bureaucracy \\
\hline
\end{tabular}




\begin{tabular}{c|c|l}
\hline Avoidance & $\bullet$ Staffing \& Resourcing & \\
& $\bullet$ & Balance between immediate and \\
Long-Term & $\bullet$ Relation building & long term benefits \\
Orientation & $\bullet$ & \\
\hline
\end{tabular}

Another interesting observation relates to uncertainty avoidance. The Dutch have a higher score in this dimension. They seek to avoid uncertainty and ambiguity by the means of formalisation - creating strict rules and algorithms, and establishing bureaucratic procedures. In contrast, the Chinese have a lower score in Uncertainty Avoidance, and hence they are not so much risk-averse. The do not necessarily take extensive risk preventing measures and formalise the project management process. The approach is more flexible and problems are tackled as they emerge.

In terms of Masculinity, the score is rather high for the Chinese, which means that the society is oriented towards achievements and success. In contracts, the Dutch have a low score, where balance between work and private life is valued, and job satisfaction is more important than career prospects.

As for Long-Term Orientation, the Chinese culture, as the Asian culture, has naturally a very high score. The society attaches more importance to the future. Building long-term relations is important in this context. The Dutch society has a medium score - this becomes apparent in project management by a balanced appetite for short and long-term results.

\subsection{Organisational culture and project management}

Our anecdotal evidence suggests that individuals working in multinational environments are susceptible to cultural change, and their national culture will gradually erode as their identity will integrate more of the elements of the organisational culture and national culture of the host country (if they are posted overseas). Our research findings are partially extending Hofstede's research in organisational and national culture that besides the fact that national culture is one of the many factors shaping organisational culture next to such factors as personality of founder, feelings of insecurity, expectations of stakeholders and type of technology in use, organisational culture plays a more important role than national culture in shaping the project management approach when comparing two organisations from two different nations, maybe because organisational culture has to be easily adapted to the different host countries such that its symptoms of symbols, heroes, and rituals can be sustainably serving the organisations for being consistent to the core of the national culture - the value. For instance, some of our interviewees claimed that, "Collectivism in China is visible as people or family, but not necessarily in my firm. The Netherlands and China do not differ much in that sense". More evidence can be found in appendix (Appendix A and Appendix B).

\subsection{Aggregated Results}

We identified a number of interesting patterns and practical problems based on four scenarios formatted by working location (China or the Netherlands) and national culture (Chinese or Dutch) as shown in 
Table 2. On the basis of our observations, we constructed three elements of project management People, Technology and Process as influencers of project performance, mitigated by culture (Figure 2).

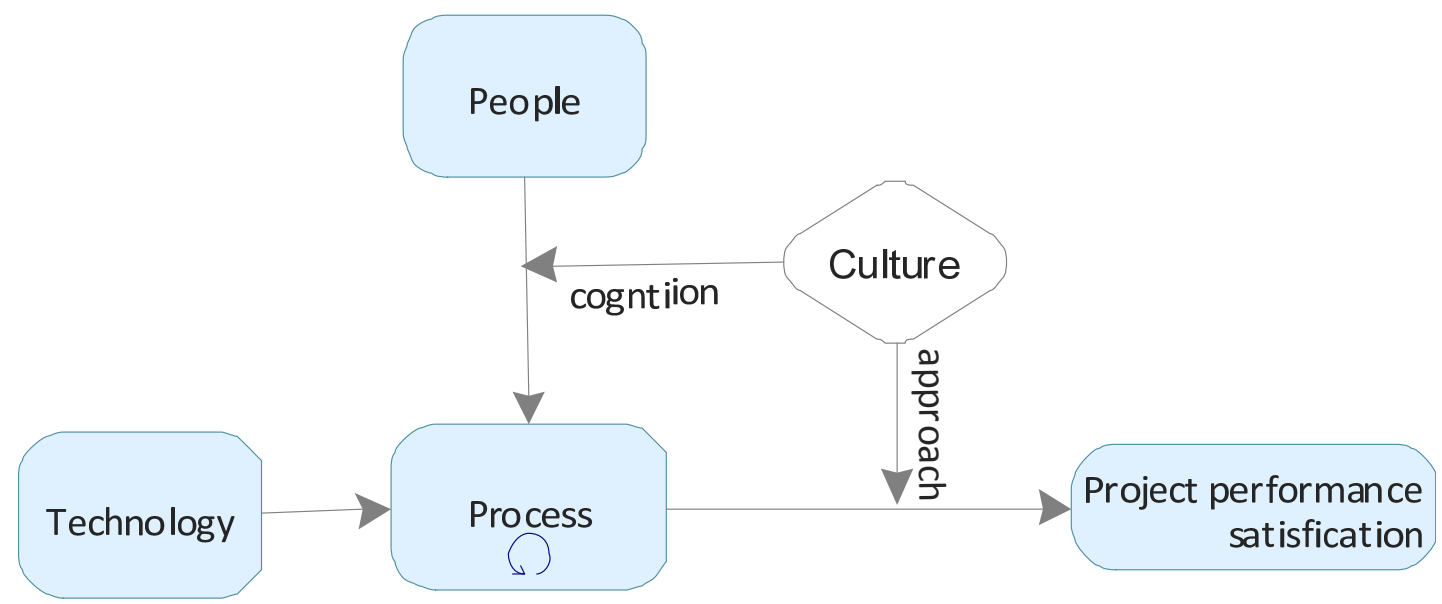

Figure 2 The role of culture in project-based environments

As indicated in Figure 2, we identified that culture acts as the essential variable to impact on project participants (people)'s cognition on project process and project outcome via collaborative working approach. There are several indications from this observation model. Firstly, in a project conducted by people from different national cultures, technology (meaning the target/ content/ instrument) of the project executes very limited impact on the final performance and the project process, due to its static nature in the project process. Second, in a comparison with technology as a whole, people are more critical to influence the whole process. We have observed that culture (regardless national culture, organisational culture, or "individual culture") has exhibited differences in influencing people's cognition in the stages of absorbing information, calculating, reasoning, problem solving, and decision making. Different processes are interpreted by people with different national cultures, and eventually present different project performance and satisfaction from participants' perspectives.

We present here our patterned observations with regard to various aspects of project management from Chinese and Dutch perspectives. Table 4 presents a summary of our findings. We analyse cross-cultural differences along various aspects of project management - cost and benefit management, governance and decision-making, quality management, planning, risk and issue management, scope management, progress management and communication.

First, when Dutch and Chinese managers work on the same project, the key factors for project management are people and process, based on the assumption that technology is treated to be identical, considering the global nature of economy and technology. Under this assumption, peoples' cognition and approach to conduct project management is largely determined by their perception and reflective perceived behaviour. The behaviour is determined by the cognition that people embrace, mainly shaped by the external environment of national culture, organisational culture, and/or individual "culture" deriving from aforementioned two cultures as well as personal traits. In such a way, process, as one of the 
key elements of project management, moderated by culture and mainly determined by people, will lead to variations in project performance.

Second, the role of organisational culture is larger than the role of national culture in shaping people's attitude and mind-set in the process of project management, maybe because organisational culture has to be easily adapted to the different host countries such that its symptoms of symbols, heroes, and rituals can be sustainably serving the organisations for being consistent to the core of the national culture - the value.

Table 4 Summary of Findings

\begin{tabular}{|c|c|c|}
\hline \multirow[t]{2}{*}{ Process } & \multicolumn{2}{|c|}{ Country / National Culture } \\
\hline & China & The Netherlands \\
\hline $\begin{array}{l}\text { Cost and benefit } \\
\text { management }\end{array}$ & $\begin{array}{l}\text { - Cost tracking important in order to } \\
\text { be competitive } \\
\text { - } \quad \text { Focus on short term benefits }\end{array}$ & $\begin{array}{l}\text { Focus on both cost and benefit } \\
\text { management }\end{array}$ \\
\hline $\begin{array}{l}\text { Governance and } \\
\text { decision making }\end{array}$ & $\begin{array}{l}\text { - } \\
\text { - } \\
\text { Decisions can be undone, } \\
\text { a contract is not always binding }\end{array}$ & $\begin{array}{ll}- & \text { More cooperative structure } \\
\text { - } & \text { Formal and oral agreements are } \\
\text { more binding }\end{array}$ \\
\hline $\begin{array}{l}\text { Quality } \\
\text { management }\end{array}$ & $\begin{array}{l}\text { - Less attention for quality } \\
\text { management, good is sometimes } \\
\text { good enough }\end{array}$ & $\begin{array}{l}\text { - Quality is as important as } \\
\text { controlling cost }\end{array}$ \\
\hline Planning & $\begin{array}{l}\text { - Project are executed at a very high } \\
\text { pace, do first plan later } \\
\text { - Planning is more dynamic and } \\
\text { flexible }\end{array}$ & 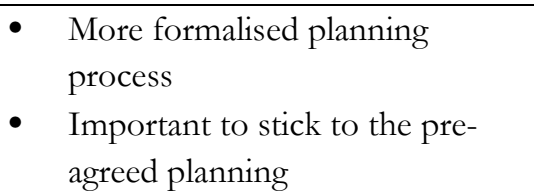 \\
\hline $\begin{array}{l}\text { Risk and issue } \\
\text { management }\end{array}$ & $\begin{array}{l}\text { - } \text { Risk appetite is higher due to } \\
\text { entrepreneurial spirit } \\
\text { - } \quad \text { More focus on issue management }\end{array}$ & $\begin{array}{l}\text { - Much time spend on identifying } \\
\text { risk beforehand } \\
\text { - } \text { Risk management is very } \\
\text { formalised }\end{array}$ \\
\hline $\begin{array}{c}\text { Scope } \\
\text { management }\end{array}$ & $\begin{array}{ll}\text { - } & \text { Project goals can easily change } \\
\text { - Decision making on scope more } \\
\text { centralised }\end{array}$ & $\begin{array}{l}\text { - } \\
\text { - } \quad \text { Formal scope management } \\
\text { process }\end{array}$ \\
\hline $\begin{array}{c}\text { Progress } \\
\text { management }\end{array}$ & $\begin{array}{ll}\text { - } & \text { Important but less formalised } \\
\text { process } \\
\text { - } & \text { Speed of delivery is essential } \\
\end{array}$ & $\begin{array}{l}\text { - Formalised and recurring process } \\
\text { (e.g. regular status reports) }\end{array}$ \\
\hline Communication & $\begin{array}{l}\text { - Not everything is discussed out in } \\
\text { the open } \\
\text { - Necessary to repeat agreements }\end{array}$ & $\begin{array}{l}\text { - Very open communication, } \\
\text { everyone has a say } \\
\text { - } \quad \text { Slower decision making }\end{array}$ \\
\hline
\end{tabular}

From our observation, there are a few differences in patterns between the Chinese and Dutch in the project process:

(1) The Dutch are more formalised in project planning process and stick more to the pre-agreed planning, while the Chinese pay less attention to planning. They execute projects with a very high pace, learning by doing, in a trial-and-error approach. Therefore, the Chinese act as more dynamically and 
efficiently in the execution stage. The Dutch spend a large part of project time in the planning stage, with the purpose of foreseeing and trying to prevent as many errors and unnecessary mistakes that might be happening later on when the project is in execution.

(2) In terms of cost and quality management, the Chinese are more focused on cost tracking in order to be competitive and hence potentially sacrificing quality in the initial stage of organisational or project development. As for scheduling and speed, the Chinese have a hierarchical governance structure but fast decision-making process. As for the Dutch, they pay attention to cost and benefits management and stick to quality control. The Dutch share a more cooperative structure so the decision-making process can be longer.

(3) In terms of risk management, the Chinese have a higher risk appetite due to their entrepreneurial spirit, but risk management is not formalised. The Dutch are more risk-averse; they spend more time on identifying risk beforehand with a very much formalised risk management system in place.

(4) In terms of scope management and project promises, the Chinese seem to be rather flexible with project goals, which are subject to changes while the project is in execution. The Dutch stick to the project goals formulated at project initiation and follow a more formalised scope management process.

(5) In terms of communication, a larger power distance in China implies that open communication in the hierarchical structure is not usual. In contrast, the Dutch holds a different approach, with a transparent communication system, open to all project team members.

Third, we have not identified any significant cross-cultural gap in project performance between the Chinese and the Dutch, although there have been many differences in the process as aforementioned. Working approaches of the Chinese and the Dutch have their own pros and cons. A combination of both approaches may lead to a win-win situation and be beneficial for project performance. For instance, the Chinese are strong in incremental innovative project and trial-and-error approach, while the Dutch feel comfortable in disruptive innovation projects, and are far more advanced in planning. Interestingly, satisfaction and project performance are rated quite high when people of both cultures work jointly on the same project. This satisfaction is even higher for Dutch managers with working experience in China partnering with Chinese managers who have a prior experience of working with Dutch colleagues (with the precondition that the leadership is appropriated in the project team).

\section{Contributions and Implications}

Cross-cultural project teams can provide all critical elements for an effective fusion of different project management practices: There is much benefit to having people from various national and organisational cultures, enriched by different experiences and management theories, with a mix of skills in the project team.

The contribution of our study lies in the explicit connection of project management and crosscultural management literature. We rely on the tenets of Geert Hofstede's studies, and apply them in the 
domain of project management. In other words, we specifically show how generic differences between different national cultures would impact particular aspects of project management. By doing so, we advance the application of Hofstede's dimensions to project phases initially put forward by Turner (2009). This study matters significantly for those who work cross culturally (western and eastern) in a globalised environment. An active and open tendency to working cross-culturally will definitely bring organisations more benefits. However it will only happen when organisations excel in managing a project in a dynamic approach.

Organisations should explicitly acknowledge the formidable value of cultural learning, especially the category of national culture, it fundamentally differs in the values and it can hardly change. For example, expatriates or members of cross-cultural project teams should consider such posting that "...it is not simply another assignment in a progression of positions or jobs, but an opportunity to acquire, create, and transfer valuable knowledge, both upon expatriation and repatriation" (Oddou et al., 2009: 182). Importance lies on the fact that every national culture has strengths and weaknesses, and matchmaking them by complementing in daily project management practice accounts significantly. The influence of cross-cultural management on project management counts in the sense that national culture difference must not only be a reason to cause the difficulties and barriers but can mostly probably facilitate the efficiency of daily project management in the category of organisational practice. Our study shows that the Dutch and the Chinese, despite a large gap in terms of culture dimensions, are able to complement and benefit each other and generate a win-win scenario, on the basis of value complementarity of national cultures in project management process and approach, in a particular compliable organisational context developed in organisational culture. This combination of managerial approaches to project management and theoretical insights from cross-cultural management is a promising research avenue, and we see significant potential for further research on the cultural differences between people of Asian and Western cultures working in project-based environments.

\section{References}

Berry, J. and Pootinga, Y. (2006). Cross-cultural theory and methodology, In Georgas, J., Berry, J., van de Vijver, F., Kagitcibasi, C. and Pootinga, Y. (Eds), Families across Cultures. Cambridge: Cambridge University Press.

Bryde, D.J. (2003). Project management concepts, methods and applications, International Journal of Operations \& Production Management, 23(7-8): 775-793

Ching Gu, V., Hoffman, J., Caoc, Q. and Schniederjans, M. (2014). The effects of organizational culture and environmental pressures on IT project performance: A moderation perspective, International Journal of Project Management, in press.

De Bony, J. (2010). Project management and national culture: A Dutch-French case study, International Journal of Project Management, 28(2): 173-182 
Deal T. and Kennedy, A. (2000). Corporate Cultures: The Rites and Rituals of Corporate Life, Harmondsworth: Penguin Books

Den Hartog, D., House, R., Hanges, P. and Ruiz-Quintanilla, S. (1999). Culture specific and crossculturally generalizable implicit leadership theories: Are attributes of charismatic/ transformational leadership universally endorsed? Leadership Quarterly, 10(2): 219-256.

Denison, D. and Mishra, A. (1995). Toward a theory of organizational culture and effectiveness, Organization Science, 6(2): 204-223.

Dorfman, P., Howell, J., Hibino, S., Lee, J., Tate, U. and Bautista, A. (1997). Leadership in western and Asian countries: Commonalities and differences in effective leadership processes across cultures, Leadership Quarterly, 8(3): 233-274.

Fangel, M. (1993). Comment: The broadening of project management, International Journal of Project Management, 11(2): 72

Gajendran, T., Brewer, G., Dainty, A. and Runeson, G. (2012). A conceptual approach to studying the organisational culture of construction projects, Australasian Journal of Construction Economics and Building, 12(2): 1-26

Gomez-Mejia, L. and Palich, L. (1997). Cultural diversity and the performance of multinational firms, Journal of International Business Studies, 28(2): 309-335.

Hofstede, G. (1997). Cultures and Organizations: Software of the Mind, McGraw-Hill

Hofstede, G., Neuijen, D., Ohayv., D., Sanders, G. (1990). Measuring orgnaizational cultures: a qualitative and quantitative study across twenty cases. Administrative Science Quarterly 35:286-316.

Javidan, M. and House, R. (2001). Cultural acumen for the global manager: Lessons from project GLOBE, Organizational Dynamics, 29(4): 289-305.

Kwak, Y.H. and Anbari, F. (2009). Analyzing project management research: Perspectives from top management journals, International Journal of Project Management, 27(5): 435-446.

Laurent, A. (1983). The cultural diversity of Western conceptions of management, International Studies of Management and Organizations, 13(1-2): 75-96.

Leung, K., Bhagat, R., Buchan, N., Erez, M. and Gibson, C. (2005). Culture and international business: Recent advances and their implications for future research, Journal of International Business Studies, 36(4): 357-378.

Maylor, H. (2005). Project Management, 3rd ed., Essex: Pearson Education Ltd

Morris, P.W.G. (1994). The Management of Projects, London: Thomas Telford

Needle, D. (2004). Business in Context: An Introduction to Business and Its Environment, London: Thompson

Oddou, G., Osland, J. and Blakeney, R. (2009). Repatriating knowledge: Variables influencing the “transfer" process, Journal of International Business Studies, 40(2): 181-199. 
Pheng, L.S. and Leong, Ch. (2000). Cross-cultural project management for international construction in China, International Journal of Project Management, 18(5): 307-316

Ravasi, D. and Schultz, M. (2006). Responding to organizational identity threats: exploring the role of organizational culture, Academy of Management Journal, 49(3): 433-458.

Rees-Caldwell, K. and Pinnington, A.H. (2013). National culture differences in project management: Comparing British and Arab project managers' perceptions of different planning areas, International Journal of Project Management, 31(2): 212-227

Ronen, S. and Shenkar, O. (1985). Clustering countries on attitudinal dimensions: A review and synthesis, Academy of Management Review, 10(3): 435-454.

Ronen, S. and Shenkar, O. (2013). Mapping world cultures: Cluster formation, sources and implications, Journal of International Business Studies, 44: 867-897

Schein, E. (2009). The Corporate Culture Survival Guide, San Francisco, CA: Jossey-Bass.

Schneider, B. (Ed) (1990). Organizational Climate and Culture, San Francisco, CA: Jossey-Bass.

Smith, P., Dugan, S. and Trompenaars, F. (1996). National culture and the values of organizational employees: A dimensional analysis across 43 nations, Journal of Cross-Cultural Psychology, 27(2): 231264.

Söderlund, J. (2004). Building theories of project management: past research, questions for the future, International Journal of Project Management, 22(3): 183-191.

Trompenaars, F. (1994). Riding the Waves of Culture: Understanding Cultural Diversity in Business. Chicago: Irwin.

Turner, J.R. (2009). The Handbook of Project-based Management: Leading Strategic Change in Organizations, $3^{\text {rd }}$ ed., New York: McGraw Hill.

Turner, J.R. (2010). Evolution of project management research as evidenced by papers published in the International Journal of Project Management, International Journal of Project Management, 28(1): 1-6.

Weber, Y., Shenkar, O. and Raveh, A. (1996). National and corporate cultural fit in mergers/acquisitions: An exploratory study, Management Science, 42(8): 1215-1227.

Wiewiora, A., Trigunarsyah, B., Murphy, G. and Coffey, V. (2013). Organizational culture and willingness to share knowledge: A competing values perspective in Australian context, International Journal of Project Management, 31(8): 1163-1174

Wintera, M., Smith, Ch., Morris, P. and Cicmil, S. (2006). Directions for future research in project management: The main findings of a UK government-funded research network, International Journal of Project Management, 24(8): 638-649.

Zeng, Y., Shenkar, O., Lee, S. and Song, S. (2013). Cultural differences, MNE learning abilities, and the effect of experience on subsidiary mortality in a dissimilar culture: Evidence from Korean MNEs, Journal of International Business Studies, 44(1): 42-65. 


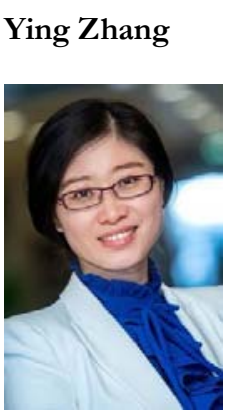

Chris Marquis

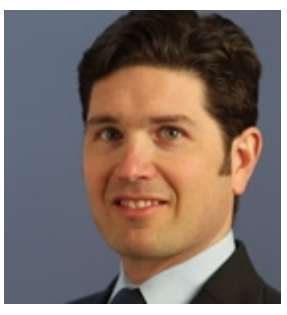

\section{Sergey Filippov}

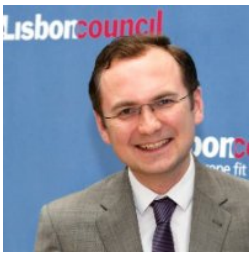

Henk-Jan

Haasnoot

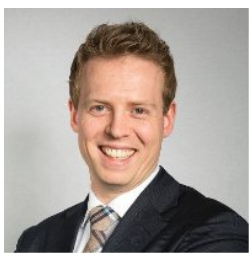

Martijn van der Steen

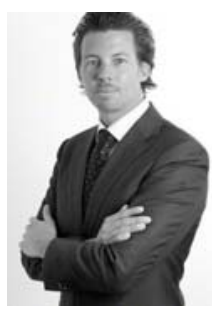

\section{About the Authors}

Dr. Ying Zhang is Associate Dean for China Business and Relations at Rotterdam School of Management (RSM). She is also an Assistant Professor at RSM. Professor Zhang's research focuses on entrepreneurship and innovation in emerging markets, examining these topics at the economic, corporate, and individual levels. More specifically, her recent research projects have examined economic transition and entrepreneurship development at the national level, social capital and firm catching up processes at the firm level, and entrepreneurial cognition as well as entrepreneurship education at the individual level. Her other research interests include corporate social responsibility, business school development, international academic collaboration, and cooperatives from emerging countries.

Dr. Chris Marquis is an Associate Professor at Harvard Business School. His current research focus is the sustainability and corporate social responsibility strategies of global corporations, with a particular emphasis on firms in China. He has published in leading management journals including, Academy of Management Journal, Academy of Management Review, Administrative Science Quarterly, American Sociological Review, California Management Review, Harvard Business Review, Organization Science, and Strategic Management Journal. Marquis is an Associate Editor at Administrative Science Quarterly and an elected member of the executive committee of the Organization and Management Theory Division of the Academy of Management.

Dr. Sergey Filippov is Associate Director at The Lisbon Council for Economic Competitiveness and Social Renewal, a leading Brussels-based innovation think-tank. Dr. Filippov oversees several initiatives, such as the European Digital Forum, liaises with policymakers, businesses and civil society, and conducts actionable policy-oriented research. Prior to joining the Lisbon Council, he served as Assistant Professor of Innovation Management at Delft University of Technology (The Netherlands), where he taught project management and conducted research in innovation management, international business and project management.

Henk-Jan Haasnoot MSc works as consultant at KPMG The Netherlands focusing on Business Transformation and Project Management. In addition he participates in the Dutch National Research Group in Project Management (DNRG) affiliated to the International Project Management Association (IPMA). Prior to this, as intern at KPMG, he has graduated from Delft University of Technology on the topic of Influences on Project Portfolio Management Adoption. As exchange student he has attended Harbin Institute of Technology in China focusing on cross-cultural management and Chinese culture. Henk-Jan is PRINCE2 ${ }^{\circledR}$ Practitioner, MSP ${ }^{\circledR}$ Foundation and IPMA level D certified.

Martijn van der Steen MSc works as consultant at KPMG The Netherlands, focusing on large-scale transformations. His main focus is the health care market, especially long-term health care. His assignments include portfolio analyses, business cases, financial analyses and project and programme management for various clients, both profit and non-profit as well as abroad. Martijn has studied Business Informatics at Utrecht University and is PRINCE2 ${ }^{\circledR}, \mathrm{MSP} \AA$ and $\mathrm{P} 3 \mathrm{O} \AA$ Practitioner certified. Within the field of project portfolio management he has a keen interest in benefits management. 
Appendix A: Hofstede's Dimensions in Practice

\begin{tabular}{|c|c|c|c|c|c|}
\hline & Respondent A & Respondent B & Respondent C & Respondent D & Respondent E \\
\hline $\begin{array}{l}\text { Power } \\
\text { Distance }\end{array}$ & $\begin{array}{l}\text { Chinese staff find it hard to } \\
\text { manage a project by nature. } \\
\text { The boss is always correct; } \\
\text { hence it is inappropriate to } \\
\text { manage colleagues. } \\
\text { In meetings Chinese } \\
\text { colleagues don't easily speak } \\
\text { up. It is a discussion between } \\
\text { the boss and Dutchmen. }\end{array}$ & $\begin{array}{l}\text { Power is with the } \\
\text { government, national but also } \\
\text { local. Governmental ties are } \\
\text { imperative to be in business. } \\
\text { International firms require } \\
\text { local partners. }\end{array}$ & $\begin{array}{l}\text { In NL the project team is } \\
\text { responsible and quite } \\
\text { autonomous. In CN the } \\
\text { company boss decides and is } \\
\text { consulted for each (major) } \\
\text { decision. }\end{array}$ & $\begin{array}{l}\text { In China the boss is the } \\
\text { boss. In NL the } \\
\text { environment is of an open } \\
\text { discussion, which is not so } \\
\text { easy in China. } \\
\text { Although changing, } \\
\text { generally in CN saying no is } \\
\text { in fact not an option, } \\
\text { neither is taking leave. This } \\
\text { leads to high productivity } \\
\text { and can be (mis)used to } \\
\text { increase workloads. } \\
\text { Workers are not always } \\
\text { informed about their rights } \\
\text { / benefits. }\end{array}$ & $\begin{array}{l}\text { Hierarchy is important in } \\
\mathrm{CN} \text { and much less in NL. } \\
\text { In NL I needed to } \\
\text { accustom myself to being } \\
\text { engaged in the thinking } \\
\text { process. CN is more } \\
\text { manager-focused. } \\
\text { Decision-making in CN is } \\
\text { clearly with one person. In } \\
\text { NL everything needs to be } \\
\text { discussed before a decision } \\
\text { is made. }\end{array}$ \\
\hline Individualism & $\begin{array}{l}\text { Collectivism in } \mathrm{CN} \text { is visible } \\
\text { as people or family, but not } \\
\text { necessarily in my firm. NL } \\
\text { and } \mathrm{CN} \text { do not differ much } \\
\text { in that sense. }\end{array}$ & $\begin{array}{l}\text { In } \mathrm{CN} \text { in projects trust is not } \\
\text { present by default, but needs } \\
\text { to be built. Mutual trust leads } \\
\text { to success. }\end{array}$ & $\begin{array}{l}\text { Not discussed/no clear } \\
\text { opinion }\end{array}$ & $\begin{array}{l}\text { In CN you are expected not } \\
\text { to stand out from the } \\
\text { group. After-work activities } \\
\text { with colleagues, like dinners } \\
\text { and drinks, are quite } \\
\text { normal. }\end{array}$ & $\begin{array}{l}\text { CN individuals focus less } \\
\text { on own ideas, but follow } \\
\text { the group opinion. CN } \\
\text { individuals are more group } \\
\text { compliant and won't speak } \\
\text { up their diverging opinion. } \\
\text { The challenge for the } \\
\text { manager is to sense this. }\end{array}$ \\
\hline Masculinity & $\begin{array}{l}\text { Chinese firms are and work } \\
\text { like one team. Credits are for } \\
\text { the team. People work very } \\
\text { hard and don't leave earlier } \\
\text { than the boss. }\end{array}$ & $\begin{array}{l}\text { Not discussed/no } \\
\text { opinion }\end{array}$ & $\begin{array}{l}\text { Chinese are no team players. } \\
\text { They keep information to } \\
\text { themselves to prevent others } \\
\text { to take advantage from it. } \\
\text { Shared goals are a new } \\
\text { concept. New innovative CN } \\
\text { firms like Huawei use this } \\
\text { more: we all benefit from } \\
\text { sharing }\end{array}$ & $\begin{array}{l}\text { Not discussed/ no clear } \\
\text { opinion }\end{array}$ & $\begin{array}{l}\text { CN knows high } \\
\text { competition and requires } \\
\text { hard work to survive. NL } \\
\text { also knows competition but } \\
\text { for other motives like job } \\
\text { satisfaction, atmosphere } \\
\text { and relations }\end{array}$ \\
\hline
\end{tabular}




\begin{tabular}{|c|c|c|c|c|c|}
\hline $\begin{array}{l}\text { Uncertainty } \\
\text { Avoidance }\end{array}$ & $\begin{array}{l}\text { CN employees individually } \\
\text { are small entrepreneurs. } \\
\text { NL firms have a tendency to } \\
\text { document and plan before } \\
\text { they start, but CN firms } \\
\text { prefer to just start and adjust } \\
\text { on the way. }\end{array}$ & $\begin{array}{l}\text { In CN safety standards are } \\
\text { still in development and } \\
\text { monitoring is not yet very } \\
\text { tight. }\end{array}$ & $\begin{array}{l}\text { CN two sided regarding risk. } \\
\text { From hierarchical perspective } \\
\text { staff behaves risk averse and } \\
\text { want approvals in order not } \\
\text { to offend anyone, for career } \\
\text { protection. On the other } \\
\text { hand, Chinese are very } \\
\text { entrepreneurial and see trade } \\
\text { opportunities everywhere. } \\
\text { They behave very flexible in } \\
\text { jumping in } \\
\text { opportunities. new } \\
\text { In PM it is important to be } \\
\text { aware of rapid societal } \\
\text { change }\end{array}$ & $\begin{array}{l}\text { Dutch are not good in } \\
\text { dealing with uncertainty. } \\
\text { Chinese can better deal with } \\
\text { change, but given the size } \\
\text { of the country change takes } \\
\text { long when considered at } \\
\text { large scale. }\end{array}$ & $\begin{array}{l}\text { Hard to generalise. Chinese } \\
\text { firms can be described as } \\
\text { entrepreneurial, whilst } \\
\text { individuals are more risk } \\
\text { averse. }\end{array}$ \\
\hline $\begin{array}{l}\text { Long-term } \\
\text { orientation }\end{array}$ & $\begin{array}{l}\text { This can be observed in } \\
\text { building relations in CN. It } \\
\text { requires investment of much } \\
\text { time in the relation before } \\
\text { business can be done. Also } \\
\text { in projects work doesn't start } \\
\text { right away. First it is required } \\
\text { to take extensive time to } \\
\text { build relations }\end{array}$ & $\begin{array}{l}\text { Highly educated Chinese } \\
\text { generally prefer to work for } \\
\text { public organisations. It is } \\
\text { challenging for private } \\
\text { international firms to recruit } \\
\text { talented Chinese people }\end{array}$ & $\begin{array}{l}\text { This is also two sided. Large } \\
\text { firms have sufficient } \\
\text { resources not to be successful } \\
\text { immediately and to wait } \\
\text { patiently for opportunities } \\
\text { due to the Chinese growth. } \\
\text { However, looking at smaller } \\
\text { (individual) level, there is a } \\
\text { desire for immediate gain } \\
\text { resulting in starting new } \\
\text { things without thorough } \\
\text { consideration. } \\
\text { economic growth allows for } \\
\text { failures, because successes } \\
\text { will compensate } \\
\text { In PM it depends on the type } \\
\text { of project. E.g. an ERP } \\
\text { implementation is considered } \\
\text { useful; however results need }\end{array}$ & $\begin{array}{l}\text { Not discussed/no clear } \\
\text { opinion }\end{array}$ & $\begin{array}{l}\mathrm{CN} \text { as a whole is long term } \\
\text { oriented, however firms } \\
\text { want gain in short term and } \\
\text { short-term focus is required } \\
\text { to survive. Long-term focus } \\
\text { would mean no pollution } \\
\text { etc but this does happen. } \\
\mathrm{NL} \text { is more balanced. } \\
\text { In terms of personal } \\
\text { relations CN is more long- } \\
\text { term oriented than NL }\end{array}$ \\
\hline
\end{tabular}


to be visible so to say the next day. 
Appendix B: Project Management Processes

\begin{tabular}{|c|c|c|c|c|c|}
\hline & Respondent A & Respondent B & Respondent C & Respondent D & Respondent E \\
\hline Planning & $\begin{array}{l}\text { - Plans are created for } \\
\text { projects, but they are } \\
\text { used in a much more } \\
\text { flexible way in } \mathrm{CN} \text { than } \\
\text { in NL }\end{array}$ & $\begin{array}{l}\text { - Projects go much faster } \\
\text { in CN, often due to } \\
\text { pressure from } \\
\text { stakeholders. } \\
\text { - Almost all projects are } \\
\text { schedule driven, } \\
\text { something has to be } \\
\text { done before a given } \\
\text { date, the deadline is } \\
\text { sacred } \\
\text { Concessions in quality } \\
\text { or a higher risker profile } \\
\text { can be the consequence } \\
\text { of this approach }\end{array}$ & $\begin{array}{l}\text { - In CN, projects often } \\
\text { just start without a } \\
\text { formal planning or the } \\
\text { planning is created } \\
\text { along the way. Speed is } \\
\text { of the essence. } \\
\text { - If something goes } \\
\text { wrong, the planning will } \\
\text { be adjusted on the spot. } \\
\text { Problem-solving } \\
\text { approach } \\
\text { escalation-driven } \\
\text { In NL, more formal } \\
\text { meetings are required in } \\
\text { order to adjust project } \\
\text { planning }\end{array}$ & $\begin{array}{l}\text { - Not interviewed on } \\
\text { planning }\end{array}$ & $\begin{array}{l}\text { - Project planning are } \\
\text { made but are less } \\
\text { formal, an agreement is } \\
\text { not always an } \\
\text { agreement in } \mathrm{CN} \text {. } \\
\text { - It is therefore to repeat } \\
\text { agreements that were } \\
\text { made in order to stay } \\
\text { aligned with the project } \\
\text { team } \\
\text { Planning is flexible and } \\
\text { dynamic in CN, it can } \\
\text { change all the time }\end{array}$ \\
\hline $\begin{array}{l}\text { Benefit and } \\
\text { cost } \\
\text { tracking }\end{array}$ & $\begin{array}{l}\text { - In NL projects are } \\
\text { often budgeted based } \\
\text { on the number of } \\
\text { expected hours, and the } \\
\text { total cost shall be } \\
\text { reflected in the bill } \\
\text { based on actual cost(s) } \\
\text { incurred } \\
\text { - In CN this is not done, } \\
\text { the cost is cost. Fixed } \\
\text { price is important } \\
\text { Chinese project team } \\
\text { members don't tend to } \\
\text { think in hours, spending } \\
\text { more time now may be } \\
\text { worthwhile in the future }\end{array}$ & $\begin{array}{l}\text { - Cost tracking is } \\
\text { important, if you are } \\
\text { not competitive on } \\
\text { price you are out of the } \\
\text { game } \\
\text { - In CN it is often } \\
\text { important that the cost } \\
\text { of products are low, } \\
\text { even if this means } \\
\text { sacrificing quality } \\
\text { The government in CN } \\
\text { has a long term vision, } \\
\text { but companies often } \\
\text { focus on a shorter } \\
\text { timeframe and therefore } \\
\text { short term benefits }\end{array}$ & $\begin{array}{l}\text { - If the goal of a project } \\
\text { is important enough, } \\
\text { the budget and thereby } \\
\text { cost tracking is } \\
\text { secondary in CN } \\
\text { - Formal business cases } \\
\text { are not often made, but } \\
\text { projects are expected to } \\
\text { achieve benefits } \\
\text { There is a notable } \\
\text { difference between } \\
\text { state-owned companies } \\
\text { and private industry; the } \\
\text { latter expects results } \\
\text { within a short timespan; } \\
\text { state-owned companies }\end{array}$ & $\begin{array}{l}\text { - Not interviewed on } \\
\text { benefit and cost } \\
\text { tracking }\end{array}$ & 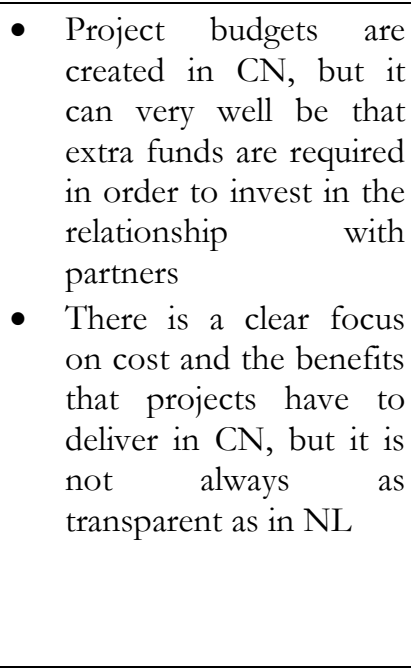 \\
\hline
\end{tabular}




\begin{tabular}{|c|c|c|c|c|c|}
\hline & $\begin{array}{l}\text { - This also relates to } \\
\text { creating long-term } \\
\text { relationships. Investing } \\
\text { in those relationships is } \\
\text { important, which will } \\
\text { eventually pay back. }\end{array}$ & $\begin{array}{l}\text { - Benefits are important } \\
\text { as there is much focus } \\
\text { on the yield of } \\
\text { investments }\end{array}$ & $\begin{array}{l}\text { have deep pockets are } \\
\text { the opinion of the } \\
\text { decision makers matters } \\
\text { most }\end{array}$ & & \\
\hline $\begin{array}{l}\text { Progress } \\
\text { managemen } \\
t\end{array}$ & $\begin{array}{l}\text { - The experience is that } \\
\text { in CN project team } \\
\text { members are not likely } \\
\text { to proactively report on } \\
\text { progress Progress- } \\
\text { reporting depends on } \\
\text { the size of the } \\
\text { company. Within } \\
\text { smaller companies it } \\
\text { can be a very informal } \\
\text { process }\end{array}$ & $\begin{array}{l}\text { - Progress management } \\
\text { and reporting in CN } \\
\text { can be a less structured } \\
\text { and less formalised } \\
\text { process compared to } \\
\text { NL } \\
\text { - Global companies often } \\
\text { have the same standards } \\
\text { and requirements } \\
\text { worldwide, so within } \\
\text { these companies there is } \\
\text { no noticeable difference }\end{array}$ & $\begin{array}{l}\text { - Speed of execution is } \\
\text { most important in } \mathrm{CN} \text {, } \\
\text { so within the process of } \\
\text { progress management } \\
\text { timely execution is } \\
\text { monitored very } \\
\text { carefully }\end{array}$ & $\begin{array}{l}\text { - Not interviewed on } \\
\text { progress management }\end{array}$ & $\begin{array}{l}\text { - In CN Progress } \\
\text { management depends } \\
\text { on planning, if there is a } \\
\text { tight schedule to be met } \\
\text { then progress } \\
\text { management becomes } \\
\text { more important } \\
\text { - More important than } \\
\text { formal progress } \\
\text { management is making } \\
\text { sure that everyone } \\
\text { understands his/her } \\
\text { task, and that } \\
\text { agreements are } \\
\text { repeated. Otherwise it } \\
\text { can become a reality on } \\
\text { paper. }\end{array}$ \\
\hline $\begin{array}{l}\text { Risk and } \\
\text { issue } \\
\text { managemen } \\
t\end{array}$ & $\begin{array}{l}\text { - In NL risk management } \\
\text { is a very formalised } \\
\text { process, and risks are } \\
\text { identified as much as } \\
\text { possible beforehand } \\
\text { - In CN, projects often } \\
\text { just start and issues are } \\
\text { dealt with as they occur. } \\
\text { Avoiding risk is less } \\
\text { important. }\end{array}$ & $\begin{array}{l}\text { - In CN, risk appetite is } \\
\text { higher than in NL and } \\
\text { therefore risk } \\
\text { management is less } \\
\text { important } \\
\text { - Issues are dealt with as } \\
\text { they occur, more } \\
\text { escalation-driven }\end{array}$ & $\begin{array}{l}\text { - Chinese project team } \\
\text { members react on issues } \\
\text { as they come along } \\
\text { - Not all potential risk are } \\
\text { identified during the } \\
\text { start up phase of a } \\
\text { project }\end{array}$ & $\begin{array}{l}\text { Not interviewed on risk } \\
\text { and issue management }\end{array}$ & $\begin{array}{l}\text { - In CN, employees or } \\
\text { project team members } \\
\text { are less likely to take } \\
\text { risks themselves, they } \\
\text { prefer to leave decision- } \\
\text { making to their boss } \\
\text { - As planning is a less } \\
\text { formalised process, risk } \\
\text { management is also less } \\
\text { formalised. A much } \\
\text { more pragmatic and } \\
\text { flexible approach is }\end{array}$ \\
\hline
\end{tabular}




\begin{tabular}{|c|c|c|c|c|c|}
\hline & & & & & used in $\mathrm{CN}$ \\
\hline $\begin{array}{l}\text { Communic } \\
\text { ation }\end{array}$ & $\begin{array}{l}\text { - No opinion on } \\
\text { communication within } \\
\text { project management }\end{array}$ & $\begin{array}{l}\text { - With regard to project } \\
\text { communication in CN } \\
\text { it is most important not } \\
\text { to disagree with major } \\
\text { stakeholders } \\
\text { - Communication is } \\
\text { focused on stakeholders } \\
\text { with the largest power } \\
\text { and influence }\end{array}$ & $\begin{array}{l}\text { - No opinion on } \\
\text { communication within } \\
\text { project management }\end{array}$ & $\begin{array}{l}\text { - Not interviewed on } \\
\text { communication }\end{array}$ & $\begin{array}{l}\text { - With regard to project } \\
\text { communication in } \mathrm{CN} \\
\text { it is most important to } \\
\text { repeat agreements and } \\
\text { common goals }\end{array}$ \\
\hline $\begin{array}{l}\text { Scope and } \\
\text { change } \\
\text { control }\end{array}$ & $\begin{array}{l}\text { - No opinion on scope } \\
\text { and change control } \\
\text { within } \\
\text { management }\end{array}$ & $\begin{array}{l}\text { - Scope and change } \\
\text { control processes are } \\
\text { useful to control risk, } \\
\text { and this occurs less in } \\
\mathrm{CN} \\
\text { - Within certain } \\
\text { industries in CN (e.g. } \\
\text { process industry) this is } \\
\text { more important than in } \\
\text { other industries }\end{array}$ & $\begin{array}{l}\text { - In CN, project goals } \\
\text { often change along the } \\
\text { way which is different } \\
\text { from NL } \\
\text { - Scope and change } \\
\text { control processes are } \\
\text { less formalised, and in } \\
\mathrm{CN} \text { they are more based } \\
\text { on the person in charge; } \\
\text { quick decision making is } \\
\text { important } \\
\text { - In NL, there is often a } \\
\text { formalised change } \\
\text { control process. }\end{array}$ & $\begin{array}{l}\text { - Not interviewed on } \\
\text { scope and change } \\
\text { control }\end{array}$ & $\begin{array}{l}\text { - No opinion on } \\
\text { communication with } \\
\text { project management }\end{array}$ \\
\hline $\begin{array}{l}\text { Quality } \\
\text { control }\end{array}$ & $\begin{array}{l}\text { - With regard to quality } \\
\text { control, good is often } \\
\text { good enough in CN but } \\
\text { it very much depends } \\
\text { on the manufacturer } \\
\text { - The key to success in } \\
\mathrm{CN} \text { is to write down } \\
\text { and discuss all the } \\
\text { product requirements/ } \\
\text { specifications in detail }\end{array}$ & $\begin{array}{l}\text { - Quality control as a } \\
\text { process has improved } \\
\text { significantly over the } \\
\text { least years in CN, but } \\
\text { there is still a gap when } \\
\text { compared to Western } \\
\text { European companies } \\
\text { - The total recordable } \\
\text { case frequency, } \\
\text { consisting of the } \\
\text { number of medical }\end{array}$ & $\begin{array}{l}\text { - Good if often good } \\
\text { enough, quality is not } \\
\text { always the most } \\
\text { important aspect. } \\
\text { - Products don't have to } \\
\text { be perfect as their } \\
\text { lifecycle is short, price } \\
\text { comes before quality } \\
\text { - This is visible in the real } \\
\text { estate industry, new } \\
\text { building often don't last }\end{array}$ & $\begin{array}{l}\text { - Not interviewed on } \\
\text { quality control }\end{array}$ & 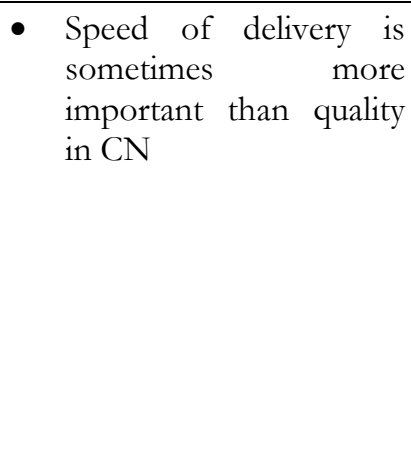 \\
\hline
\end{tabular}




\begin{tabular}{|c|c|c|c|c|c|}
\hline & & $\begin{array}{l}\text { treatment } \\
\text { restricted work cases, } \\
\text { and lost time injuries } \\
\text { has improved much } \\
\text { over the last years but } \\
\text { there are still } \\
\text { improvements to be } \\
\text { made }\end{array}$ & longer than 20 years & & \\
\hline $\begin{array}{l}\text { Governanc } \\
\text { e and } \\
\text { decision } \\
\text { support }\end{array}$ & $\begin{array}{llr}\text { - No opinion } & \text { on } \\
\text { governance } & \text { and } \\
\text { decision support } & \end{array}$ & $\begin{array}{l}\text { - The boss decides in } \\
\mathrm{CN} \text {, but it also depends } \\
\text { on the (local) political } \\
\text { situation in CN } \\
\text { - It is not always easy to } \\
\text { tell who really pulls the } \\
\text { strings }\end{array}$ & $\begin{array}{l}\text { - The boss always } \\
\text { decides, and even in } \\
\text { larger companies most } \\
\text { decision making on } \\
\text { projects goes via the } \\
\text { CEO in CN } \\
\text { - In NL, project decision } \\
\text { making is a process } \\
\text { where more people } \\
\text { have a formal say }\end{array}$ & $\begin{array}{ll}\text { - Not interviewed on } & \text { on } \\
\text { governance } & \text { and } \\
\text { decisions support } & \end{array}$ & $\begin{array}{llr}\text { No opinion } & \text { on } \\
\text { governance } & \text { and } \\
\text { decision support } & \end{array}$ \\
\hline
\end{tabular}

